\title{
The Structure of MS-3: A Glyoxalase I Inhibitor Produced by a Mushroom
}

\author{
Shyogo Kurasawa, Hiroshi Naganawa, Tomio Takeuchi \\ and Hamao UMEZAWA \\ Institute of Microbial Chemistry, Kamiosaki, \\ Shinagawa-ku, Tokyo, Japan \\ Received May 19, 1975
}

\begin{abstract}
The structure of MS-3, a glyoxalase $I$ inhibitor produced by a mushroom, was established to be $3^{\prime}, 4^{\prime}$-dihydroxymethyl-5'-hydroxy-6'-(3-methyl-2-butenyl)-phenyl-2, 4-dihydroxy6-methyl-benzoate.
\end{abstract}

As reported in our previous paper, ${ }^{1)}$ MS-3, a glyoxalase I inhibitor, was obtained as colorless needles from a cultured broth of a mushroom.

In the present paper we describe the structure of MS-3 (I). Previous observations ${ }^{1)}$ of IR spectrum, UV spectrum, color reactions, and $\mathrm{p} K a$ a values suggest the presence of phenolic hydroxyl, ester, and alkyl groups and the absence of free carboxylic acid in I.

The molecular formula, $\mathrm{C}_{21} \mathrm{H}_{24} \mathrm{O}_{7}$ was indicated by elementary analysis. This formula was supported by PMR spectrum and ${ }^{13} \mathrm{C}$ NMR (CMR) spectrum, shown later.

As shown in Fig. 1, the PMR spectrum of I in octadeuterodioxane shows five hydroxyl groups $(\delta 11.31,1 \mathrm{H}, \mathrm{s} ; \delta 8.80,1 \mathrm{H}, \mathrm{s} ; \delta 8.44$, $1 \mathrm{H}, \mathrm{s} ; \delta 4.62,1 \mathrm{H}, \mathrm{t}, J=5.2 \mathrm{~Hz} ; \delta 3.78,1 \mathrm{H}$, t, $J=6.2 \mathrm{~Hz}$; each exchange with $\mathrm{D}_{2} \mathrm{O}$ ), four olefinic protons $(\delta 6.64,1 \mathrm{H}, \mathrm{s} ; \delta 6.26$ and 6.18 , $2 \mathrm{H}, \mathrm{m} ; \delta 5.06,1 \mathrm{H}, \mathrm{m})$, three methylene groups $(\delta 4.91,2 \mathrm{H}, \mathrm{d}, J=5.2 \mathrm{~Hz} ; \delta 4.50,2 \mathrm{H}, \mathrm{d}, J=$ $6.2 \mathrm{~Hz} ; \delta 3.26,2 \mathrm{H}$, broad d, $J=7.0 \mathrm{~Hz}$ ), and three methyl groups $(\delta 2.60,3 \mathrm{H}, \mathrm{s} ; \delta 1.55,3 \mathrm{H}$ $\times 2, \mathrm{~m})$.

Five hydroxyl groups can be assigned as follows: one phenolic hydroxyl group $(\delta$ $11.31)$ in hydrogen bonding, two nonchelated phenolic hydroxyl groups $(\delta 8.80, \delta 8.44)$ and two primary alcoholic hydroxyl groups $(\delta$ $4.62, \delta 3.78)$. An ester carbonyl $\left(1655 \mathrm{~cm}^{-1}\right)$ was suggested by IR to be in the hydrogen bonding. Three olefinic protons at lower field
( $\delta 6.64,6.26,6.18$ ) are considered to be aromatic protons. The irradiation of methyl signal at $\delta 2.60$ caused two protons at $\delta 6.26$ and 6.18 multiplet to collapse to $\mathrm{AB}$ quartet pattern $(J=2.5 \mathrm{~Hz})$, as shown in Fig. 1. This indicates that a couple of protons are located in meta positions. Two alcoholic hydroxyl groups $(\delta 4.62,3.78)$ and two methylene groups $(\delta 4.91,4.50)$ are assigned to two hydroxymethyl groups $\left(-\mathrm{CH}_{2} \mathrm{OH}\right)$ attached to an aromatic ring.

Irradiation at $\delta 3.26$ caused one proton multiplet at $\delta 5.06$ to collapse to a broad singlet. Moreover, as shown in Table I, irradiation of two methyl resonance $\left(\begin{array}{ll}\delta & 1.55\end{array}\right)$ gave a $20 \%$ increase in the integrated area of the methine proton ( $\delta$ 5.06) and a small $(8 \%)$ but apparently clear increase in the integrated area of the methylene group ( $\delta 3.26)$. These results indicate the presence of a $-\mathrm{CH}_{2}-\mathrm{CH}=$ $\mathrm{C}<{ }_{\mathrm{CH}_{3}}^{\mathrm{CH}_{3}}$ moiety. One methyl group ( $\delta 2.60$ ) is assigned to be attached to an aromatic ring.

The assignments described above results in a basal skeleton and the functional groups of $\mathrm{I}$ as follows:

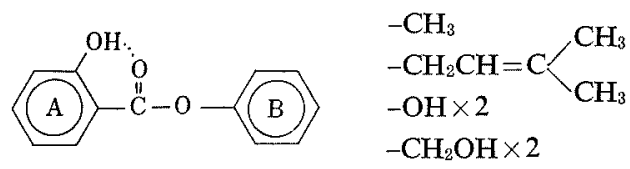

These assignments were also supported by the chemical shifts of carbons in CMR spectrum of 


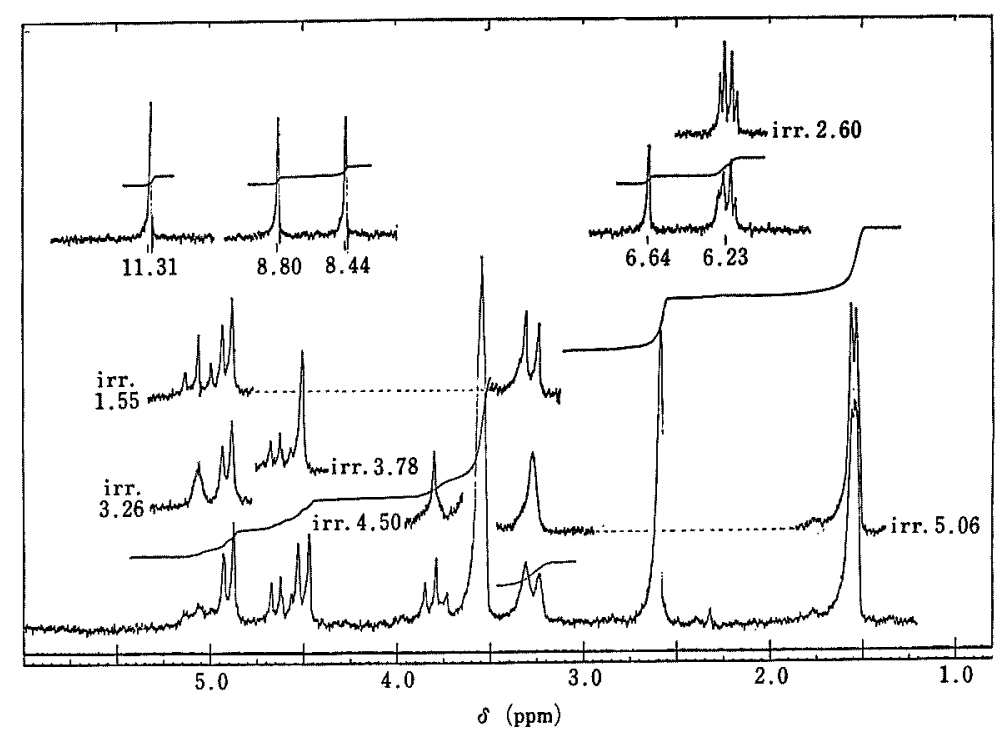

Fig. 1. PMR Spectrum of MS-3 (I) in Dioxane-d8.

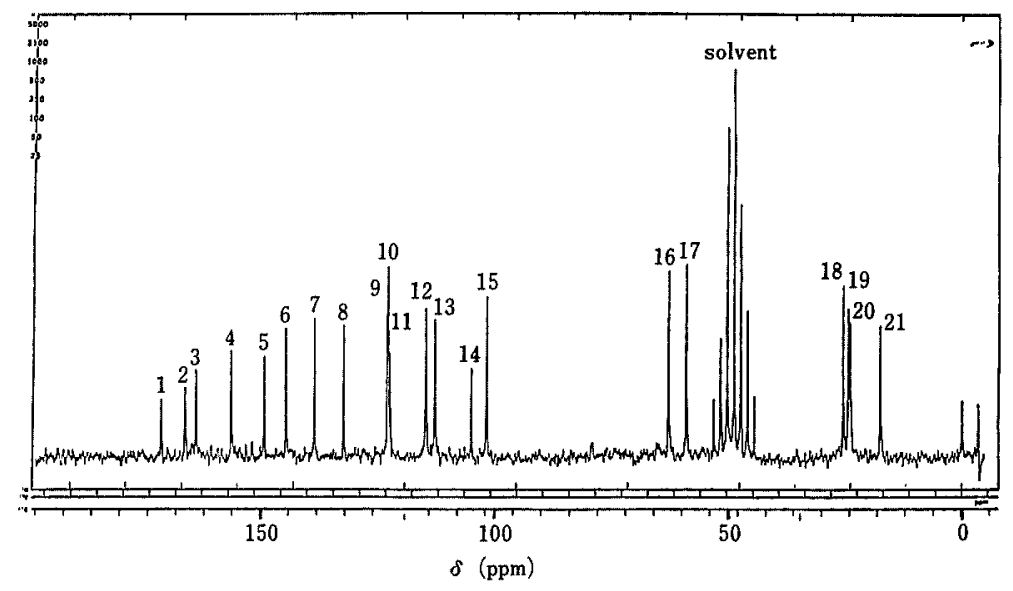

FIG. 2. CMR Spectrum of MS-3 (I) in $\mathrm{CD}_{3} \mathrm{OD}$.

I in tetradeuteromethanol, as shown in Fig. 2. Consequently, the structural study of $I$ has led to a decision on the positions of these functional groups.

As shown in Table I, NOE are observed between methyl protons ( $\delta 2.60)$ and an aromatic proton $(\delta 6.26)$, between aromatic protons $(\delta 6.18,6.26)$ and a nonchelated phenolic hydroxyl proton ( $\delta 8.44$ ), and between an aromatic proton ( $\delta$ 6.18) and a chelated phenolic hydroxyl proton ( $\hat{\delta} 11.31$ ). These results suggest that two aromatic protons in meta positions, two phenolic hydroxyl groups and one methyl group are attached to the aromatic ring $\mathrm{A}$. Therefore, $\mathrm{A}$ ring moiety of I should be IA, as shown below.<smiles>Cc1cc(O)cc(O)c1C(=O)O</smiles>

IA

Furthermore, in NOE experiments of $I$ as shown in Table I, irradiation of one methylene resonance $(\delta 4.50)$ gave a $33 \%$ increase in the integrated area of an aromatic proton $(\delta 6.64)$. This result suggests that one hydroxymethyl 
Table I. NOE of MS-3 (I) IN Dioxane-d8

\begin{tabular}{|c|c|c|c|c|}
\hline \multicolumn{2}{|c|}{$\begin{array}{l}\text { Proton signal, } \\
\text { observed } \\
(\delta, \mathrm{ppm})\end{array}$} & \multicolumn{2}{|c|}{$\begin{array}{l}\text { Proton signal, } \\
\text { saturated } \\
(\delta, \mathrm{ppm})\end{array}$} & $\begin{array}{c}\% \text { In- } \\
\text { crease in } \\
\text { integrated } \\
\text { area of signal }\end{array}$ \\
\hline $\mathrm{Ar}-\mathrm{CH}_{2}^{-}$ & $(3.26)$ & & & 8 \\
\hline$-{ }_{-}^{\prime} \mathrm{CH}-$ & $(5.06)$ & 0 & ( & 20 \\
\hline $\begin{array}{l}\mathrm{Ar}-\mathrm{H} \\
\mathrm{Ar}-\mathrm{H}\end{array}$ & $\begin{array}{l}(6.18) \\
(6.26)\end{array}$ & $\mathrm{Ar}-\mathrm{OH}$ & $(8$. & $\begin{array}{l}18 \\
18\end{array}$ \\
\hline$-\mathrm{H}$ & $(6.2$ & $\mathrm{Ar}-\mathrm{CH}_{3}$ & $(2.60)$ & 15 \\
\hline $\mathrm{r}-\mathrm{H}$ & $(6.6$ & $\mathrm{Ar}-\mathrm{CH}_{2-}$ & $(4.50)$ & 33 \\
\hline $\mathrm{Ar}-\mathrm{OH}$ & $(8.80)$ & $\mathrm{Ar}-\mathrm{CH}_{2-}$ & $(4.91)$ & 33 \\
\hline $\begin{array}{l}\mathrm{Ar}-\mathrm{OH} \\
\mathrm{Ar}-\mathrm{OH}\end{array}$ & $\begin{array}{r}(8.44) \\
(11.31)\end{array}$ & $\mathrm{Ar}-\mathrm{H}, \mathrm{H}$ & $(6.23)$ & $\begin{array}{r}26 \\
8\end{array}$ \\
\hline
\end{tabular}

group is located at the ortho position to the aromatic proton of $\mathbf{B}$ ring. Irradiation at $\delta 4.50$ gave a $33 \%$ increase in the integrated area of the phenolic hydroxyl ( $\delta 8.80)$. From these results, the following possible partial structure in ring $\mathrm{B}$ of $\mathrm{I}$ can be proposed:
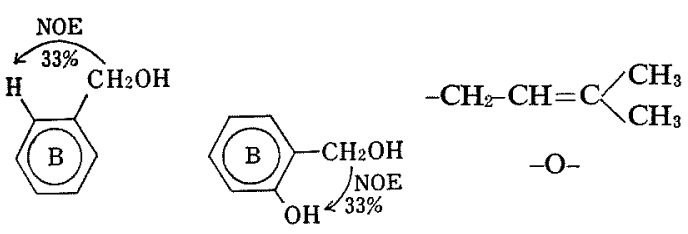

I is methylated with diazomethane giving a mixture of the monomethyl derivative $\left(\mathrm{II}_{1}\right)$ and the dimethyl derivative $\left(\mathrm{II}_{2}\right)$. PMR spectrum of $\mathrm{II}_{2}$ shows that the nonchelated two phenolic hydroxyl groups are methylated. $\mathrm{II}_{2}$ is easily hydrolyzed with $\mathrm{KOH}$ in methanolic solution, yielding two compounds (III and
IV). Isolation of the corresponding hydrolysis product from I was unsuccessful.

The molecular formula of III, $\mathrm{C}_{10} \mathrm{H}_{12} \mathrm{O}_{4}$ was shown by elemental analysis and mass analysis $\left(\mathrm{M}^{+}\right.$196). PMR spectrum of III, as shown in Fig. 3, in deuterochloroform indicates that this compound is derived from $\mathrm{A}$ ring of $\mathrm{II}_{2}$, but has two methoxy groups. One methoxy group is due to $\mathrm{II}_{2}$, another one is newly formed to give methylester group during hydrolysis in alkaline methanolic solution. Consequently, III is considered to be sparassol. The melting point of sparassol has been reported $^{2\}} 63 \sim 65^{\circ} \mathrm{C}$. III showed $\mathrm{mp} 65^{\circ} \mathrm{C}$. Identity of III as sparassol was proved by mixed $\mathrm{mp}$ and the complete coincidence in UV, IR, PMR, and mass spectrum. Therefore, A ring moiety of I should be orsellinic acid.<smiles>COC(=O)c1c(C)cc(OC(C)=O)cc1O</smiles>

III (Sparassol)<smiles>Cc1cc(O)cc(O)c1C(=O)O</smiles>

Orsellinic acid
The molecular formula of IV, $\mathrm{C}_{14} \mathrm{H}_{20} \mathrm{O}_{4}$, was shown by elemental analysis and mass analysis $\left(M^{+} 252\right)$. IV was easily shown to be derived from $\mathrm{B}$ ring of $\mathrm{II}_{2}$ by hydrolysis. PMR spectrum in hexadeuteroacetone of IV, as shown in Fig. 4, indicates the presence of a new phenolic hydroxyl signal $(\delta 8.19,1 \mathrm{H}, \mathrm{s})$.

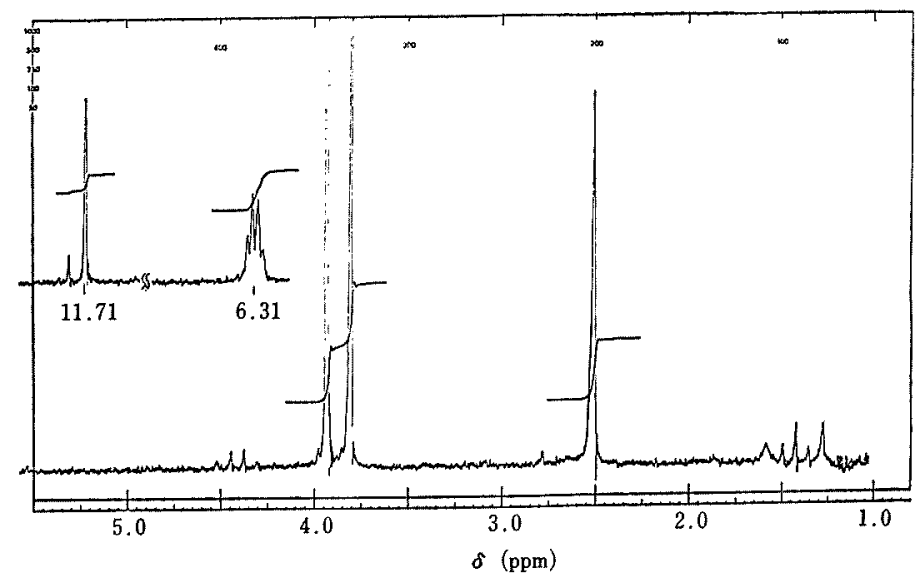

FIG. 3. PMR Spectrum of III in $\mathrm{CDCl}_{3}$. 


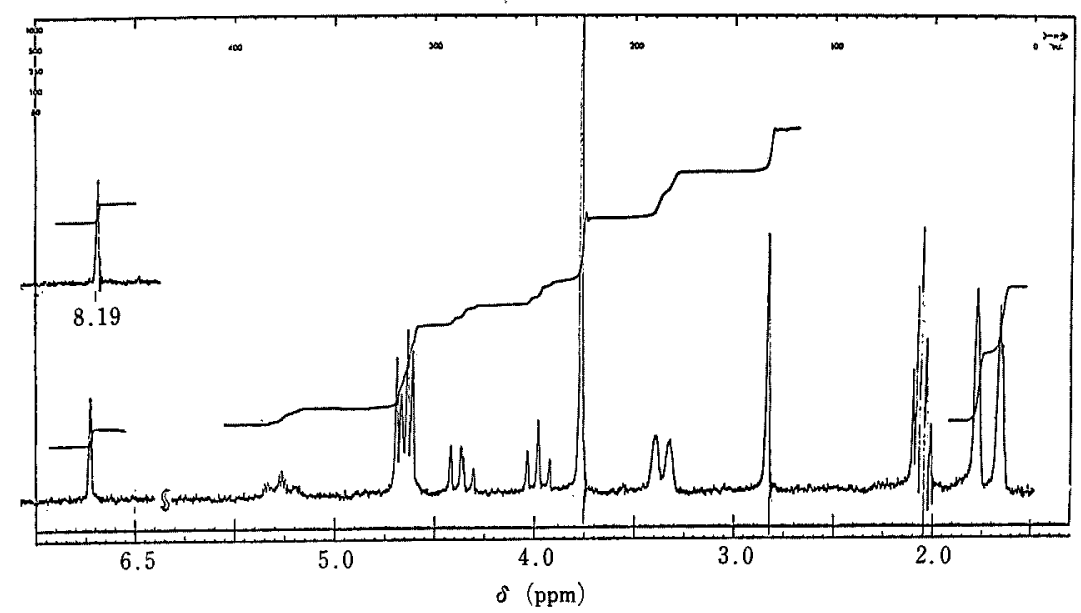

FIG. 4. PMR Spectrum of IV in Acetone- $\mathrm{d}_{6}$.

Irradiation of the aromatic proton ( $\delta 6.71)$ and the methylene protons $(\delta 3.35)$ of $3-$ methyl-2-butenyl group gave $20 \%$ and $10 \%$ increases, respectively, of integrated areas of phenolic hydroxyl ( $\delta$ 8.19). These results suggest that the formulae of IV is $I_{a}$ or $I V_{b}$.
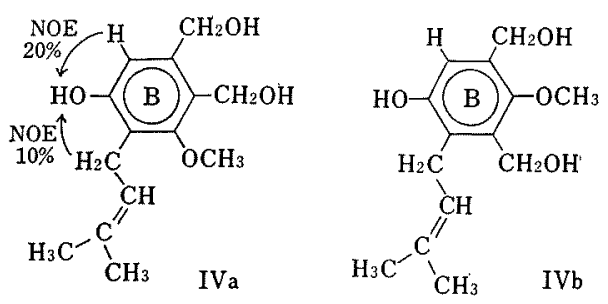

The aliphatic olefin of I was easily converted to aldehyde by ozonolysis." The ozonolysis product (V) of I was investigated to determine the sturcture of aromatic ring $B$. PMR spectrum of $\mathrm{V}$ in hexadeuterodimethyl sulfoxide is shown in Fig. 5.

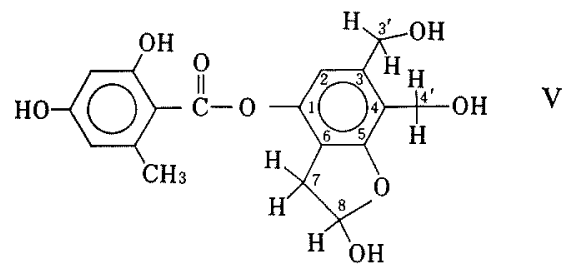

Irradiation at $\delta 5.18\left(3^{\prime}-\mathrm{OH}, \mathrm{t}, J=5.5 \mathrm{~Hz}\right)$ and $\delta 4.65\left(4^{\prime}-\mathrm{OH}, \mathrm{t}, J=5.0 \mathrm{~Hz}\right)$ caused two proton doublets at $\delta 4.50(J=5.0 \mathrm{~Hz})$ and $\delta$ $4.65(J=5.5 \mathrm{~Hz})$ to collapse to two singlets, respectively. It indicates that these two hydroxymethyl groups did not undergo ozonolysis. Irradiation of the methylene resonance $(\delta 4.65$, $\left.2 \times 3^{\prime}-\mathbf{H}\right)$ gave a $27 \%$ increase in the integrated area of the aromatic proton $(\delta 6.78$, 2-H). Irradiation at $\delta 6.07(8-\mathrm{H})$ caused methylene protons at $\delta 2.76\left(7-\mathrm{H}_{1}\right)$ and $\delta 3.26$ $\left(7-\mathrm{H}_{2}\right)$ to collapse to a $\mathrm{AB}$ type splitting of $J=$ $17.0 \mathrm{~Hz}$. Irradiation at $\delta 3.0\left(7-\mathrm{H}_{1}, \mathrm{H}_{2}\right)$ caused one proton multiplet at $\delta 6.07(8-\mathrm{H})$ to collapse to a broad doublet $(J=3.0 \mathrm{~Hz})$. Irradiation at $\delta 7.35(8-\mathrm{OH})$ caused one proton multiplet at $\delta 6.07(8-\mathrm{H})$ to collapse to a quartet $(J=3.2,6.4 \mathrm{~Hz})$. These results indicate that the phenolic hydroxyl group and the 3methyl-2-butenyl group of B ring of I formed a 5-membered hemiacetal ring during ozonolysis. Treatment of $\mathrm{V}$ with $\mathrm{Br}_{2}$ after acetylated with acetic anhydride-pyridine resulted in an absorption at $1780 \mathrm{~cm}^{-1}$ characteristic of 5-membered lactone carbonyl, and an absorption of ester carbonyl at $1740 \mathrm{~cm}^{-1}$ Therefore, the ozonolysis product was determined to be $V$.

From the chemical and spectral data described above, the structure of MS-3 was established to be I, $3^{\prime}, 4^{\prime}$-dihydroxymethyl-5'hydroxy - 6' - (3-methyl-2-butenyl) -phenyl-2, 4dihydroxy-6-methyl-benzoate. 


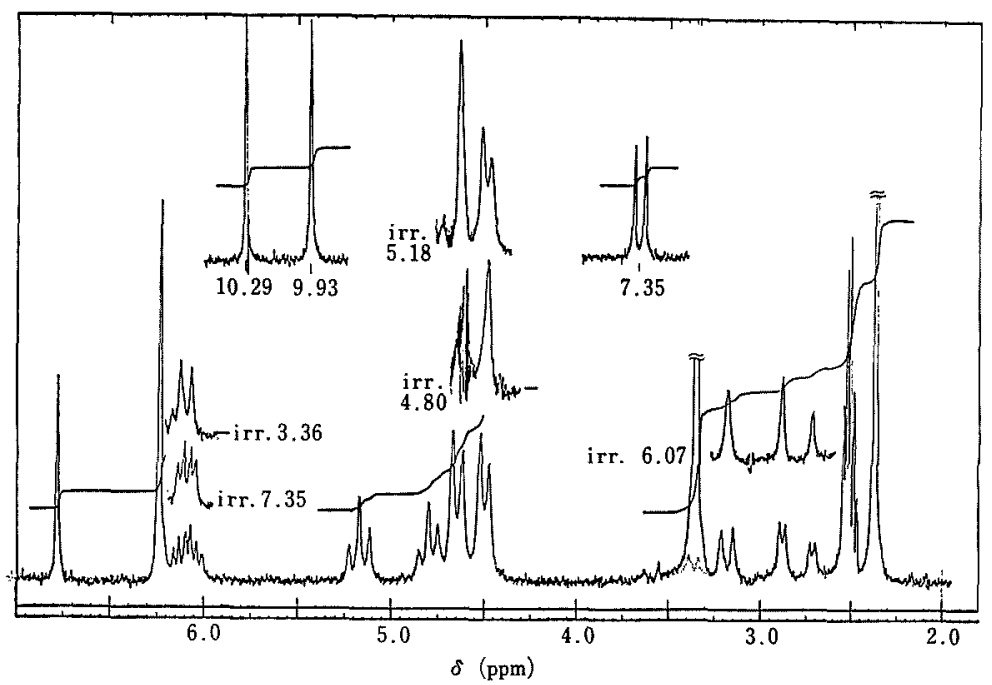

FIG. 5. PMR Spectrum of Ozonolysis Product of $I(V)$ in DMSO- $d_{6}$.<smiles>CC(C)=CCc1c(OC(=O)c2c(C)cc(O)cc2O)cc(CO)c(CO)c1O</smiles>

The presence of this compound has not yet been reported. Therefore, MS-3 is a new depside compound.

As described in a previous paper, ${ }^{1)}$ MS-3 underwent degradation when added to liver homogenates. After the degradation, orsellinic acid was detected by thin-layer chromatography, and hydrolysis by an esterase was suggested. It may be the reason for the $a b-$ sence of MS-3 activity in vivo.

\section{EXPERIMENTAL}

UV spectra were obtained by Hitachi EPS-2U spectrophotometer. IR spectra were taken as $\mathrm{KBr}$ disks by Hitachi EPI-S2 Infrared spectrometer. NMR spectra were taken by Varian HA-100D (PMR) and NV-14 (CMR) spectrometers, and chemical shifts were given in parts per million $(\delta)$ downfield from the internal standard, TMS $(\delta=0.00 \mathrm{ppm})$. Abbreviation: $s=$ singlet, $\mathrm{d}=$ doublet, $\mathrm{t}=$ triplet, $\mathrm{dd}=$ doublet of doublets, $\mathrm{q}=$ quartet, $\mathrm{m}=$ multiplet. The mass spectra were taken by Hitachi RMU-6M and $-7 \mathrm{M}$ spectrometers.

$M S-3(I)$

I showed $\mathrm{mp} 92^{\circ} \mathrm{C}$ and no optical rotation. I is positive to ammonium phosphomolybdate, potassium ferricyanide- $\mathrm{FeCl}_{3}$, hydroxamic acid- $\mathrm{FeCl}_{3}$ and $\mathrm{KMnO}_{4}$, but negative to ninhydrin, Fehling, and Molish. pKá values in $50 \% \mathrm{MeOH}$ solution showed 8.85 and 10.38. UV $\lambda_{\max }^{\mathrm{MeOH}} \mathrm{nm}(\varepsilon): 270(23,280), 305(8,630)$. IR $\nu_{\max }^{\mathrm{KBr}} \mathrm{cm}^{-1}: 3400,2950,1655,1615,1580,1495,1440$, $1430,1375,1320,1255,1190,1165,1095,1060,1035$, 990, 885, 845, 790, 695. PMR (dioxane-d 8 ) $\delta: 1.55$ $\left(6 \mathrm{H}, \mathrm{m},\left(\mathrm{CH}_{3}\right)_{2} \mathrm{C}=\mathrm{CH}-\right), 2.60\left(3 \mathrm{H}, \mathrm{s}, \mathrm{Ar}-\mathrm{CH}_{3}\right), 3.26$ $\left(2 \mathrm{H}, \mathrm{d}, J=7.0 \mathrm{~Hz}, \mathrm{Ar}-\mathrm{C} \underline{H}_{2} \mathrm{CH}=\right), 3.78(1 \mathrm{H}, \mathrm{t}, J=6.2 \mathrm{~Hz}$, $\left.-\mathrm{CH}_{2}-\mathrm{OH}\right), 4.50\left(2 \mathrm{H}, \mathrm{d}, J=6.2 \mathrm{~Hz}, \mathrm{Ar}-\mathrm{CH}_{2}-\mathrm{OH}\right), 4.62$ $\left(1 \mathrm{H}, \mathrm{t}, J=5.2 \mathrm{~Hz},-\mathrm{CH}_{2}-\underline{\mathrm{OH}}\right), 4.91(2 \mathrm{H}, \mathrm{d}, J=5.2 \mathrm{~Hz}$, $\left.\mathrm{Ar}-\mathrm{CH}_{2}-\mathrm{OH}\right), 5.06\left(1 \mathrm{H}, \mathrm{m}, J=7.0 \mathrm{~Hz},-\mathrm{CH}_{2}-\mathrm{CH}=\mathrm{C}\right)$, 6.18 and $6.24(2 \mathrm{H}, \mathrm{AB} \mathrm{q}, J=2.5 \mathrm{~Hz}, \mathrm{Ar}-\underline{\mathrm{H}}), 6.64(1 \mathrm{H}$, $\mathrm{s}, \mathrm{Ar}-\underline{\mathrm{H}}$ ), 8.44, 8.80 and 11.31 (each $1 \mathrm{H}, \mathrm{s}, \mathrm{Ar}-\underline{\mathrm{OH}}$ ). CMR $\left(\mathrm{MeOH}-\mathrm{d}_{4}\right) \delta: \quad 171.6,166.6,164.3,156.8,149.6$, $145.0,138.9,132.7,123.0,122.9,122.7,115.0,113.0$, 105.2, 101.9, 62.9, 59.1, 25.8, 24.6, 24.2, 17.7. Anal. Found: C, 64.91; H, 6.19; O, 28.59\%. Calcd. for $\mathrm{C}_{21} \mathrm{H}_{24} \mathrm{O}_{7}: \mathrm{C}, 64.93 ; \mathrm{H}, 6.23 ; \mathrm{O}, 28.84 \%$.

Methylation of $I\left(I I_{1}\right.$ and $\left.I_{2}\right)$

A solution of I ( $300 \mathrm{mg}$ ) in $\mathrm{MeOH} 4 \mathrm{ml}$ and ether $11 \mathrm{ml}$ was treated with an excess of ethereal diazomethane and allowed to stand for $3 \mathrm{hr}$ at room temperature. The solution showed two UV absorbing spots ( $R f 0.39$ and 0.52 ) on a silica gel TLC (solvent system: $\mathrm{CHCl}_{3}-\mathrm{MeOH} 20: 1$ ). The solution was concentrated and was chromatographed on silica gel $(20 \mathrm{~g})$ using $\mathrm{CHCl}_{3}-\mathrm{MeOH}(99: 1)$ as a developing solvent. The eluates was concentrated separately to give $75 \mathrm{mg}$ of $\mathrm{II}_{1}\left(R f 0.39\right.$ on TLC) and $195 \mathrm{mg}$ of $\mathrm{II}_{2}(R f 0.52 \mathrm{on}$ TLC). 
Monomethyl derivative of $I\left(I I_{1}\right)$. Recrystallization from chloroform gave colorless needles, $\mathrm{mp} 141 \sim 146^{\circ} \mathrm{C}$. PMR (dioxane- $\mathrm{d}_{8}$ ) $\delta: 1.55(6 \mathrm{H}, \mathrm{m}$, two methyls), 2.63 (3H, s, methyl), 3.25 ( $2 \mathrm{H}, \mathrm{d}$, methylene), $3.70(1 \mathrm{H}, \mathrm{t}$, $\mathrm{OH}), 3.80(3 \mathrm{H}, \mathrm{s}, \mathrm{OMe}), 4.50(2 \mathrm{H}, \mathrm{d}$, methylene), 4.60 $(1 \mathrm{H}, \mathrm{t}, \mathrm{OH}), 4.90(2 \mathrm{H}, \mathrm{d}$, methylene), $5.05(1 \mathrm{H}, \mathrm{m}$, methine), $6.40(2 \mathrm{H}, \mathrm{s}$, two $\mathrm{Ar}-\mathrm{H}), 6.65(1 \mathrm{H}, \mathrm{s}, \mathrm{Ar}-\mathrm{H})$, 8.78 and 11.32 (each $1 \mathrm{H}, \mathrm{s}, \mathrm{Ar}-\mathrm{OH}$ ). Anal. Found: C, $65.67 ; \mathrm{H}, 6.49 \%$. Calcd. for $\mathrm{C}_{22} \mathrm{H}_{26} \mathrm{O}_{7}$ : C, 65.66; H, $6.51 ; \mathrm{O}, 27.83 \%$.

Dimethyl derivative of $I\left(I I_{2}\right)$. Recrystallization from chloroform gave colorless needles, $\mathrm{mp} 132 \sim 133^{\circ} \mathrm{C}$. PMR $\left(\mathrm{CDCl}_{3}\right) \delta: 1.53(6 \mathrm{H}, \mathrm{m}$, two methyls), $2.62(3 \mathrm{H}$, $\mathrm{s}$, methyl), 3.34 ( $2 \mathrm{H}, \mathrm{d}$, methylene), 3.82 and 3.85 (each $3 \mathrm{H}, \mathrm{s}, \mathrm{OMe}), 4.75$ ( $2 \mathrm{H}, \mathrm{s}$, methylene), 4.82 ( $2 \mathrm{H}, \mathrm{s}$, methylene), $5.05(1 \mathrm{H}, \mathrm{m}$, methine), $6.35(2 \mathrm{H}, \mathrm{s}$, two $\mathrm{Ar}-\mathrm{H}), 6.90(1 \mathrm{H}, \mathrm{s}, \mathrm{Ar}-\mathrm{H}), 11.42(1 \mathrm{H}, \mathrm{s}, \mathrm{Ar}-\mathrm{OH})$. Anal. Found: C, $66.57 ; \mathrm{H}, 6.78 \%$. Calcd. for $\mathrm{C}_{23} \mathrm{H}_{28} \mathrm{O}_{7}$ : C, $66.33 ; \mathrm{H}, 6.78 ; \mathrm{O}, 26.89 \%$.

\section{Hydrolysis of $\mathrm{II}_{2}$ (III and IV)}

A $10 \% \mathrm{MeOH}$ solution of $\mathrm{II}_{2}(140 \mathrm{mg})$ in $0.1 \mathrm{~N} \mathrm{KOH}$ $(70 \mathrm{ml})$ was allowed to stand for two hours at room temperature, and then adjusted to $\mathrm{pH} 6.0$ with $6 \mathrm{~N} \mathrm{HCl}$. The solution was extracted with EtOAc, washed with water, and then evaporated. The residue by TLC on silica gel (solvent system: benzene-acetone $2: 1$ ) showed two $\mathrm{KMnO}_{4}$ positive spots of $R f 0.92$ and 0.32 . III $(R f 0.92)$ and IV $(R f 0.32)$ were isolated by silica gel column chromatography developed with benzeneacetone $(5: 1)$. Each fraction was evaporated.

III (sparassol). III was crystallized from benzene, producing $50 \mathrm{mg}$ of colorless crystals, $\mathrm{mp} 65^{\circ} \mathrm{C}$. [lit., ${ }^{2 /}$ $\left.\mathrm{mp} 63 \sim 65^{\circ} \mathrm{C}\right] \quad$ IR $\nu_{\max }^{\mathrm{E} \mathrm{Br}} \mathrm{cm}^{-1}: 2940,1645,1615,1570$, $1455,1440,1420,1375,1328,1297,1268,1215,1150$, 1066, 1042, 997, 950, 863, 812, 775, 695. PMR $\left(\mathrm{CDCl}_{3}\right)$ $\delta: 2.51(3 \mathrm{H}, \mathrm{s}, \mathrm{Ar}-\mathrm{Me}$ ), 3.81 and 3.93 (each $3 \mathrm{H}, \mathrm{s}, \mathrm{OMe}$ ), 6.29 and $6.34(2 \mathrm{H}, \mathrm{AB} \mathrm{q}, J=2.5 \mathrm{~Hz}, \mathrm{Ar}-\mathrm{H}), 11.71$ (1H, s, Ar-OH). Anal. Found: C, 62.27; H, 6.40\%. Calcd. for $\mathrm{C}_{10} \mathrm{H}_{12} \mathrm{O}_{4}$ (MW. 196): C, 6.21; H, 6.17; O, 32.62\%. MS m/e Found: $196.0757\left(\mathrm{M}^{+}\right)$, Calcd. 196.0735 .

IV. IV was crystallized from chloroform, giving $67 \mathrm{mg}$ of colorless crystals, $\mathrm{mp} 132^{\circ} \mathrm{C}$. IR $\nu_{\max }^{\mathrm{KBr}} \mathrm{cm}^{-1}$ :
$3500,3340,3000,2940,1615,1600,1440,1375,1322$, $1285,1238,1225,1195,1163,1090,1048,1010,990,895$, 863, 782, 720. PMR (acetone- $d_{6}$ ) $\delta: 1.65$ and 1.78 (each $3 \mathrm{H}, \mathrm{s}$, methyls), $3.35(2 \mathrm{H}, \mathrm{d}, J=7.0 \mathrm{~Hz}$, methylene), 3.77 ( $3 \mathrm{H}, \mathrm{s}, \mathrm{OMe}$ ), 3.98 ( $1 \mathrm{H}, \mathrm{t}, J=5.5 \mathrm{~Hz}, \mathrm{OH}$ ), $4.36(1 \mathrm{H}, \mathrm{t}, J=5.5 \mathrm{~Hz}, \mathrm{OH}), 4.63(2 \mathrm{H}, \mathrm{d}, J=5.5 \mathrm{~Hz}$, methylene), $4.66(2 \mathrm{H}, \mathrm{d}, J=5.5 \mathrm{~Hz}$, methylene), 5.26 (1H, $\mathrm{m}, J=7.0 \mathrm{~Hz}$, methine), $6.72(1 \mathrm{H}, \mathrm{s}, \mathrm{Ar}-\mathrm{H}), 8.19$ (1H, s, Ar-OH). Anal. Found: C, 66.42; H, 7.93\%. Calcd. for $\mathrm{C}_{14} \mathrm{H}_{20} \mathrm{O}_{4}$ (MW. 252): C, 66.64; H, 7.99; $0,25.37 \%$. MS $m / e$ Found: $252.1350\left(\mathrm{M}^{+}\right)$, Calcd. 252.1360 .

\section{Ozonolysis of $I(V)$}

A solution of $\mathrm{I}(100 \mathrm{mg})$ in $\mathrm{MeOH}(12 \mathrm{ml})$ was ozonized at $-30^{\circ} \mathrm{C}$ for $8 \mathrm{~min}$. The solution was flushed with nitrogen gas to remove the remained ozone. The ozonide was decomposed with dimethyl sulfide $(0.15 \mathrm{ml})$ by the method of Pappas et al. ${ }^{3}$ The ozonolysis product was evaporated and then chromatographed on a column of silica gel $(20 \mathrm{~g})$ using $\mathrm{CHCl}_{3}-\mathrm{MeOH}(15: 1)$ as a developing solvent. The eluate was concentrated to give $\mathrm{V}(60 \mathrm{mg})$ as white powder. $\mathrm{IR} \nu_{\max }^{\mathrm{KBr}} \mathrm{cm}^{-1}$ : $3450 \sim 3100,2870,2700,1665,1590,1475,1445,1422$, $1355,1315,1260,1190,1170,1105,1055,1010,990,950$, $880,860,840,785,760,690,665$. PMR (DMSO-d $\left.\mathrm{d}_{6}\right) \delta$ : 2.37 ( $3 \mathrm{H}, \mathrm{s}, \mathrm{Ar}-\mathrm{Me}), 2.76(1 \mathrm{H}$, dd, $J=3.2$ and $17.0 \mathrm{~Hz}$ ), $3.26(1 \mathrm{H}, \mathrm{dd}, J=6.4$ and $17.0 \mathrm{~Hz}), 4.50(2 \mathrm{H}, \mathrm{d}, J=$ $5.0 \mathrm{~Hz}), 4.65(2 \mathrm{H}, \mathrm{d}, J=5.5 \mathrm{~Hz}), 4.80(1 \mathrm{H}, \mathrm{t}, J=5.0 \mathrm{~Hz}$, $\mathrm{OH}), 5.18(1 \mathrm{H}, \mathrm{t}, J=5.5 \mathrm{~Hz}, \mathrm{OH}), 6.07(1 \mathrm{H}, \mathrm{m}), 6.23$ $(2 \mathrm{H}, \mathrm{s}, \mathrm{Ar}-\mathrm{H}), 6.67(1 \mathrm{H}, \mathrm{s}, \mathrm{Ar}-\mathrm{H}), 7.35(1 \mathrm{H}, \mathrm{d}, J=$ $6.4 \mathrm{~Hz}, \mathrm{OH}), 9.93(1 \mathrm{H}, \mathrm{s}, \mathrm{Ar}-\mathrm{OH}), 10.29(1 \mathrm{H}, \mathrm{s}$, $\mathrm{Ar}-\mathrm{OH}$ ).

Acknowledgement. The authors express their appreciation to Dr. M. Ohno, Toray Industries Inc., for his helpful advice.

\section{REFERENCES}

1) S. Kurasawa, T. Takeuchi and H. Umezawa, Agr. Biol. Chem., 39, 2003 (1975).

2) J. Herzig, F. Wenzel and F. Kurzweil, Monatsh., 24, 895 (1903).

3) J. J. Pappas, W. P. Keaveney, E. Gancher and M. Berger, Tetrahedron Letters, 4273 (1966). 